\title{
MODELOWANIE OBIEKTÓW TOPOGRAFICZNYCH W BAZACH DANYCH HISTORYCZNYCH
}

\begin{abstract}
Zarys treści: Celem artykułu jest zaproponowanie koncepcji modelowania obiektów topograficznych w bazach danych historycznych w celu integracji geometrycznej i topologicznej. Głównym źródłem danych są mapy archiwalne w różnych skalach opracowane na przestrzeni 150 lat (od przełomu XVIII/XIX do połowy XX wieku). Ze względu na różnorodność materiałów źródłowych w celu integracji geometrii danych topograficznych zaproponowano podejście oparte na metodzie retrogresywnej.
\end{abstract}

Słowa kluczowe: geografia historyczna, GIS, bazy danych, mapy archiwalne, modelowanie kartograficzne.

\section{Wprowadzenie i stan badań}

Pojawienie się Systemu Informacji Geograficznej (GIS) wraz z bazami danych i możliwością szybkiej wizualizacji przechowywanych $\mathrm{w}$ nich elementów zrewolucjonizowało sposoby prowadzenia badań nie tylko w geografii, ale także w innych dyscyplinach nauk o ziemi. Zainteresowanie historyków tym narzędziem sprawiło, że jesteśmy świadkami coraz częstszego wykorzystania GIS także w badaniach nad przeszłością, w szczególności z zakresu geografii historycznej. Możliwość efektywnego pozyskiwania, analizowania i prezentowania historycznych danych geograficznych zapoczątkowała aplikowanie GIS w pracach badawczych zarówno o charakterze opisowo-rekonstrukcyjnym, jak i edycyjnym (por. Szady 2010; Nieścioruk 2013; Gochna 2014).

Niezwykle istotną składową GIS jest baza danych, w której przechowywane są informacje przestrzenne $\mathrm{i}$ atrybutowe wraz $\mathrm{z}$ określonymi relacjami pomiędzy nimi. W przypadku danych historycznych należy uwzględnić przede wszystkim problem czasu i wynikających z niego konsekwencji, takich jak: zmiana atrybutów obiektu, zmiana jego położenia, jego istnienia bądź nieistnienia w ciągu danego okresu itd. Stąd problem opracowania struktury bazy danych obiektów historycznych był już wielokrotnie poruszany w literaturze, zarówno przez geografów, historyków, jak i informatyków (Langran 1989; Gregory 2002; 
Dukaczewski 2005; Gregory, Healey 2007; Reis Ferreira i in. 2010; Morillas-Torné 2012; Szady 2013).

Według I.N. Gregory'ego (2002) często stosowanymi metodami opracowania historycznych baz danych przestrzennych są: Time-slice snapshots (Langran 1992) i Date-stamping (Vrana 1990). Pierwsza zakłada tworzenie szeregu osobnych tabel dla obiektów dla poszczególnych lat tak, że w każdej występują zjawiska z jednego okresu. Ten prosty $\mathrm{i}$ łatwy w opracowaniu model jest jednak niezwykle narażony na redundancję danych. Druga $\mathrm{z}$ możliwości zakłada umieszczanie wszystkich obiektów w jednej tabeli wraz z „czasem” jako atrybutem, co nie pozwala jednak na konstruowanie relacji między wcześniejszymi lub późniejszymi stanami.

Ciekawszą propozycją jest metoda Space-time composite opracowana przez G. Langran (1989) do modelowania powierzchni, np. użytkowania ziemi. Każdy obszar jest podzielony na najmniejsze, możliwie jednorodne pod względem danych atrybutów fragmenty i każdemu z nich przypisany zostaje identyfikator. Są one także elementem tabeli przechowującej dane atrybutowe, np. wydzielenia użytkowania ziemi, która jest uzupełniona informacją o dacie. Dzięki zbudowaniu relacji pomiędzy tabelami możliwe jest połączenie danych geometrycznych i atrybutowych. W rezultacie $w$ bazie danych nie ma redundancji, a ewentualne błędy topologiczne mogą być szybko wychwytywane.

Nieco podobną metodą, nazwaną „referencyjno-retrospektywną”, posłużył się D. Dukaczewski (2005) podczas opracowywania bazy danych do elektronicznej mapy animowanej Gór Izerskich. Głównym założeniem repozytorium było zintegrowanie informacji przestrzennej o pokryciu terenu $\mathrm{z}$ okresu od przełomu XVIII/XIX wieku do czasów współczesnych. Autor posługiwał się zobrazowaniami satelitarnymi, które służyły za podstawę geometrycznej korekcji dawnych map jako materiałów w dużej mierze niekartometrycznych. Dzięki temu powstała baza danych tzw. „stanów jednoczasowych” reprezentujących stan pokrycia terenu na dany rok, która była podstawą do opracowania mapy zmian w postaci animowanej wizualizacji.

Z punktu widzenia teoretycznych podstaw baz danych historycznych istotne jest także poszukiwanie własności konstytutywnych obiektów historycznych, np. elementów osadnictwa. Dyskusja na temat cech, które jednoznacznie identyfikują obiekt w czasie i przestrzeni, toczy się wokół pojęć, takich jak: nazwa, położenie czy status (miasto/wieś). Wszystkie te atrybuty, które dotyczą pojedynczej jednostki osadniczej, mogą ulegać zmianie na przestrzeni lat (Szady 2013).

Zagadnieniem integracji i harmonizacji historycznych danych przestrzennych zajmował się także zespół z Zakładu Geoinformatyki, Kartografii i Teledetekcji UW (Gołębiowska i in. 2012; Panecki 2014). Przedstawiona została koncepcja tzw. „metalegendy” dla dawnych map. Ma być ona semantyczną nadbudową istniejących na mapach kluczy znaków i definiować dla nich „metakategorie”. 
Poszczególne elementy treści mapy w ramach warstw tematycznych mogą zostać zestawione na jednolitej płaszczyźnie znaczeniowej, np. osadnictwo, drogi, obiekty gospodarcze. „Metalegenda” w postaci bazy danych atrybutowych treści map będzie uwzględniać: oryginalną nazwę wydzielenia pochodzącą z mapy i wybrane atrybuty jako podtypy, np. szerokość drogi, liczba torów, wielkość osady. W ten sposób nastąpi harmonizacja danych bez straty informacji źródłowej.

\section{Założenia i metody badań}

Głównym założeniem opracowywanej struktury bazy danych historycznych obiektów topograficznych jest oparcie jej na kartograficznej podstawie źródłowej uzupełnianej o informacje słownikowe, statystyczne i instrukcje opracowania map. Głównym źródłem danych będą mapy archiwalne opracowane w różnych skalach, przez różne ośrodki, państwa i twórców na przestrzeni 150 lat. Ramy chronologiczne otwiera okres od przełomu XVIII i XIX wieku, gdy dzięki coraz powszechniejszemu stosowaniu triangulacji i pomiarów stolikowych mapy cechowały się stosunkowo niewielkimi zniekształceniami. Cezurą zamykającą analizy jest połowa XX wieku, tj. początku powojennego kartowania obszaru Polski dla map w układzie „1942”. Porównywanie krajobrazu geohistorycznego między mapami $\mathrm{z}$ tych lat zostanie umożliwione dzięki powiązaniu struktury projektowanego repozytorium z opracowywanymi współcześnie bazami danych przestrzennych, tj. Bazą Danych Obiektów Topograficznych (BDOT10K) (Olszewski, Gotlib 2013). Odniesienie danych historycznych do BDOT10K sprawia, że obszarem badawczym będzie Polska we współczesnych granicach.

Głównym celem autora niniejszego artykułu jest przedstawienie wstępnej koncepcji modelowania obiektów topograficznych w bazach danych historycznych w celu integracji geometrii danych źródłowych. Można bowiem zastanowić się, w jaki sposób powinna być zapisywana geometria dla poszczególnych obiektów pozyskanych z map: czy każdy z nich ma mieć osobny zapis położenia (Time-slice snapshots) czy efektywniejsze i bardziej poprawne byłoby opracowanie siatki „metaobiektów” o stałej geometrii, ale zmiennych atrybutach (Space-time composite)? Niezależnie od obranego podejścia, podstawą teoretyczną rozważań jest koncepcja modelowania kartograficznego, które można zdefiniować jako przetwarzanie rzeczywistości geograficznej w uporządkowany informatycznie zbiór danych ukazujący najważniejsze cechy modelowanego zjawiska i pomijający te nieistotne (Głażewski 2006).

Należy pamiętać, że cała ta problematyka jest wieloaspektowa i nie da się jej wyczerpać, opierając się jedynie na podejściu metodycznym. Bardzo ważnym aspektem powinien być także walor poznawczy, wynikający $\mathrm{z}$ zagadnienia modelowania danych przestrzennych. W tym wypadku powinna być to ocena przydatności archiwalnych map topograficznych jako podstawy opracowania 
baz danych przestrzennych, np. poprzez porównanie zakresu i metod ujęcia treści dawnych map. W kontekście bazy danych nie może zabraknąć aspektu aplikacyjnego i określenia jej potencjalnych zastosowań i użytkowników. Projektowane repozytorium, oparte na mapach topograficznych, zapewni podstawy umożliwiające porównywanie zmian zachodzących w krajobrazie geohistorycznym na przestrzeni lat oraz prowadzenie takich analiz z wykorzystaniem GIS.

\section{Modelowanie topograficznych danych historycznych}

Mapa jako pewien obraz i model przestrzeni jest źródłem nie tylko danych opisowych (atrybutowych), ale przede wszystkim przestrzennych (geometrycznych). Informuje użytkownika nie tylko o typie czy rodzaju zjawiska (droga II klasy, miasto handlowe, las mieszany), ale w pierwszej kolejności o jego rozmieszczeniu. Położenie obiektu w przestrzeni można ująć dwojako: jako relacje z przyjętym układem odniesienia (współrzędne geograficzne, współrzędne prostokątne płaskie) oraz $\mathrm{w}$ odniesieniu do pozostałych obiektów na mapie, tj. określenie położenia obiektów poprzez relacje topologiczne (sąsiedztwo, przecinanie, zawieranie etc.). $\mathrm{W}$ bazie danych przestrzennych informację geometryczną o obiekcie zapisuje się jako jeden z jego atrybutów: określa się typ geometrii (punkt, linia, powierzchnia) oraz zapisuje się położenie lub punkty węzłowe w przyjętym układzie odniesienia zgodnie z przyjętą precyzją danych (Urbański 2008).

Trudności w zapisie prawidłowych współrzędnych obiektów w bazie danych historycznych są spowodowane niespójnością topologiczną zachodzącą między zidentyfikowanymi tymi samymi obiektami na różnych mapach dawnych (tzw. metaobiektami). Kartometryczność map wpływa na lokalizację symboli kartograficznych reprezentujących fragmenty rzeczywistości geograficznej względem układu współrzędnych przyjętego na mapie. Jak wiadomo, matematyczna poprawność oraz precyzja dawnych map jest różna, a błędy położenia obiektów (w porównaniu z mapami współczesnymi) sięgają od kilkudziesięciu metrów (Messtischblatt) do kilku kilometrów (mapa von Schmettau'a) ${ }^{1}$.

Czy zatem błędne położenie obiektu, a raczej błędny zapis tego położenia na mapie powinien być brany pod uwagę przy określaniu geometrii obiektu? Jest to kwestia dyskusyjna i zależna $\mathrm{w}$ dużej mierze od tego, czy analizowany obiekt jest elementem krajobrazu kulturowego czy naturalnego. W zależności od typu krajobrazu, składające się na niego obiekty cechują się mniejszą lub większą niezmiennością w czasie i przestrzeni.

Dla przykładu, dla zagród olęderskich przedstawianych na mapach Urmesstischblatt z 1828 roku i Messtischblatt z 1940 roku można z dużą dozą

${ }^{1}$ A. Konias (2010) szacuje dokładność mapy von Schmettau'a z końca XVII wieku na ok. 1,5 km, a Messtischblatt z przełomu XIX/XX wieku na ok. $44 \mathrm{~m}$. 
prawdopodobieństwa przyjąć ich tożsamość, mimo różnic w zakodowaniu ich w przestrzeni. Różnice $\mathrm{w}$ położeniu zagród na Urmesstischblatt względem Messtischblatt to około 50-150 m (rys. 1). Mimo wszystko, dzięki relacjom topologicznym z innymi elementami treści mapy można stwierdzić, że poszczególne zagrody z Urmesstischblatt odpowiadają zagrodom z Messtischblatt. Można zatem zapisać w bazie danych informację o ich położeniu, posiłkując się mapą Messtischblatt, na której błędy położenia obiektów są mniejsze niż na Urmesstischblatt. Gdy jednak na bardziej kartometrycznej mapie niemożliwe jest zidentyfikowanie obiektu z mapy wcześniejszej (mniej kartometrycznej), informację o jego położeniu można zapisać, posiłkując się starszym materiałem, w tym przypadku Urmesstischblatt.

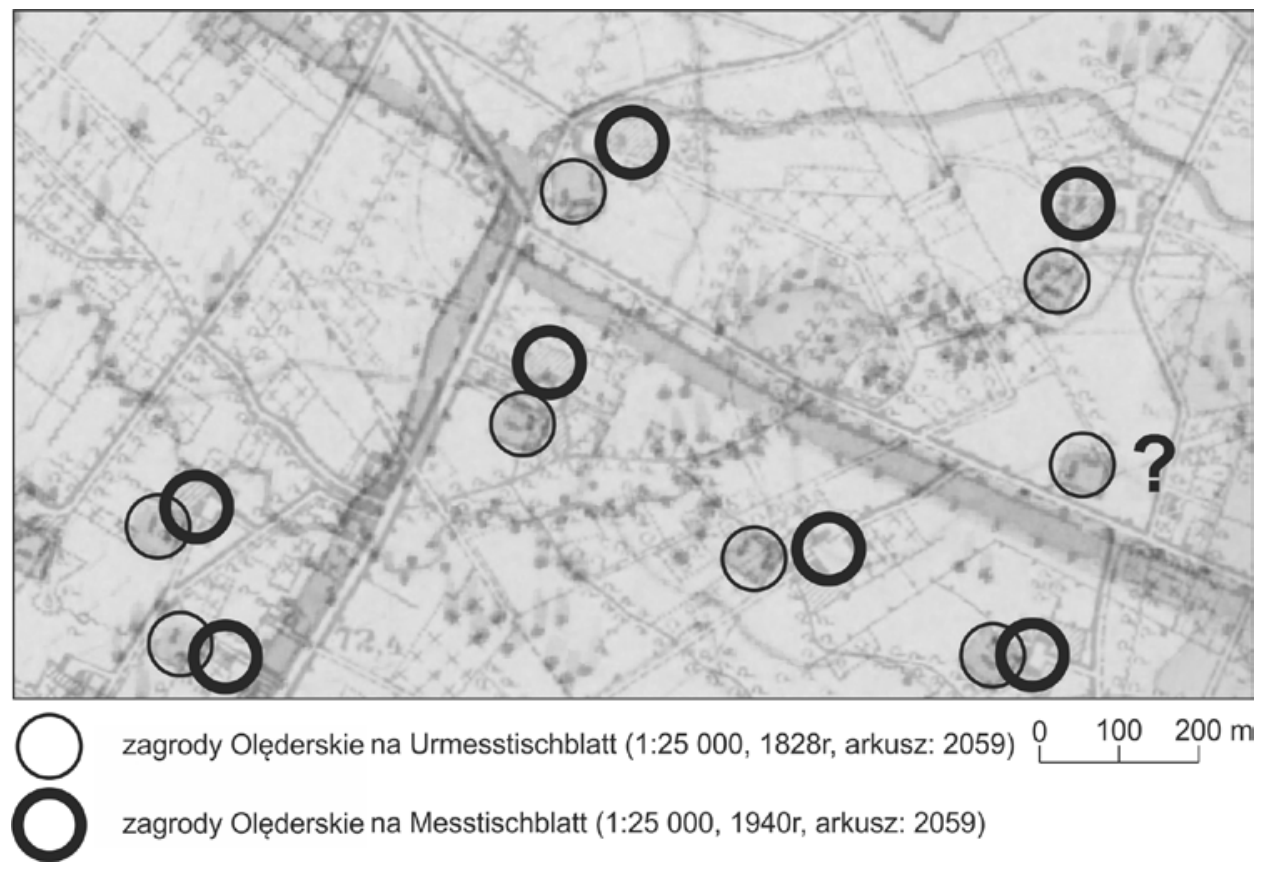

Rys. 1. Obraz osadnictwa olęderskiego w okolicach Nowego Tomyśla na mapach Urmesstischblatt i Messtischblatt

Źródło: opracowanie własne

$\mathrm{Z}$ inną interpretacją możemy mieć do czynienia w przypadku elementów krajobrazu naturalnego, np. rzek, jezior, lasów. W tej sytuacji różnice w położeniu, kształcie i powierzchni tych obiektów na różnych mapach mogą wynikać nie tylko z błędnego zapisu przestrzennego (np. niskiej kartometryczności map), ale także z rzeczywistej zmiany tych parametrów w ciągu omawianego okresu. Rzeki, jeziora czy lasy nie są przecież stałymi i niezmiennymi przestrzennie składowymi krajobrazu. Kształt obiektów hydrograficznych warunkowany jest chociażby procesami geomorfologicznymi (erozja i akumulacja osadów 
rzecznych; meandrowanie) czy antropogenicznymi (melioracje, obniżenie poziomu wód gruntowych). Z kolei lasy podlegały w czasach historycznych karczunkom, ale możliwe były także ich przyrosty. Czy zatem dokonując krytyki kartograficznego źródła historycznego i określając jego kartometryczność jako niską, mamy prawo do pominięcia zapisu geometrii na jego podstawie dla tych elementów treści, o których wiemy, że są zmienne w czasie i przestrzeni?

Rozwiązanie problemu zapisu $\mathrm{w}$ bazie danych geometrii historycznych obiektów topograficznych może polegać albo na wektoryzacji każdego z nich osobno, co będzie skutkowało różnym położeniem, przebiegiem lub kształtem obiektów, albo na przyjęciu jednolitego położenia w układzie współrzędnych dla zidentyfikowanych tych samych obiektów (tzw. metaobiektów), np. odcinków dróg czy pojedynczych zagród, które nie zmieniły położenia, a jedynie atrybuty (por. rys. 1).

W pierwszym przypadku geometria będzie określona indywidualnie dla każdego obiektu. Wektoryzacja tego samego elementu treści z różnych map będzie jednak z reguły skutkowała pewnymi przesunięciami takiego obiektu względem innych, co będzie wynikać nie tylko z niedostatecznej kartometryczności map czy poprawności i jakości jej kalibracji w GIS, ale także z precyzji wektoryzacji mapy przez operatora. Efektem takiego postępowania, np. dla kilku odcinków tej samej drogi zwektoryzowanych z map opracowywanych w różnych latach będą ich wzajemne przesunięcia między sobą, co ilustruje rys. 2. Największe błędy położenia dróg można zaobserwować na najstarszej mapie - Urmesstischblatt, jednak nawet treść map dwudziestowiecznych cechuje się pewnym przesunięciem względem siebie.

Z punktu widzenia konstrukcji bazy danych, takie zachwianie topologii jest niedopuszczalne, gdyż może prowadzić do mylnego wniosku, że dany obiekt na przestrzeni lat zmienił swoje położenie lub przebieg. Tymczasem przesunięcia obiektów na różnych mapach mogą wynikać nie tyle z ich zmiany w przestrzeni, ale $\mathrm{z}$ niepoprawnego kodowania położenia obiektów na mapę przez dawnych kartografów, co ma związek z niską kartometrycznością dawnych map. Można zatem zaryzykować stwierdzenie, że wektoryzacja elementów treści z map obarczonych błędami położenia obiektów jest niepoprawna i oznaczałaby de facto wprowadzanie do bazy danych informacji przestrzennej o niskiej jakości w myśl idei garbage in - garbage out. Innymi słowy, pozyskiwanie błędnych informacji na wejściu skutkuje ich powielaniem na dalszych etapach analiz (Wolski 2012). 


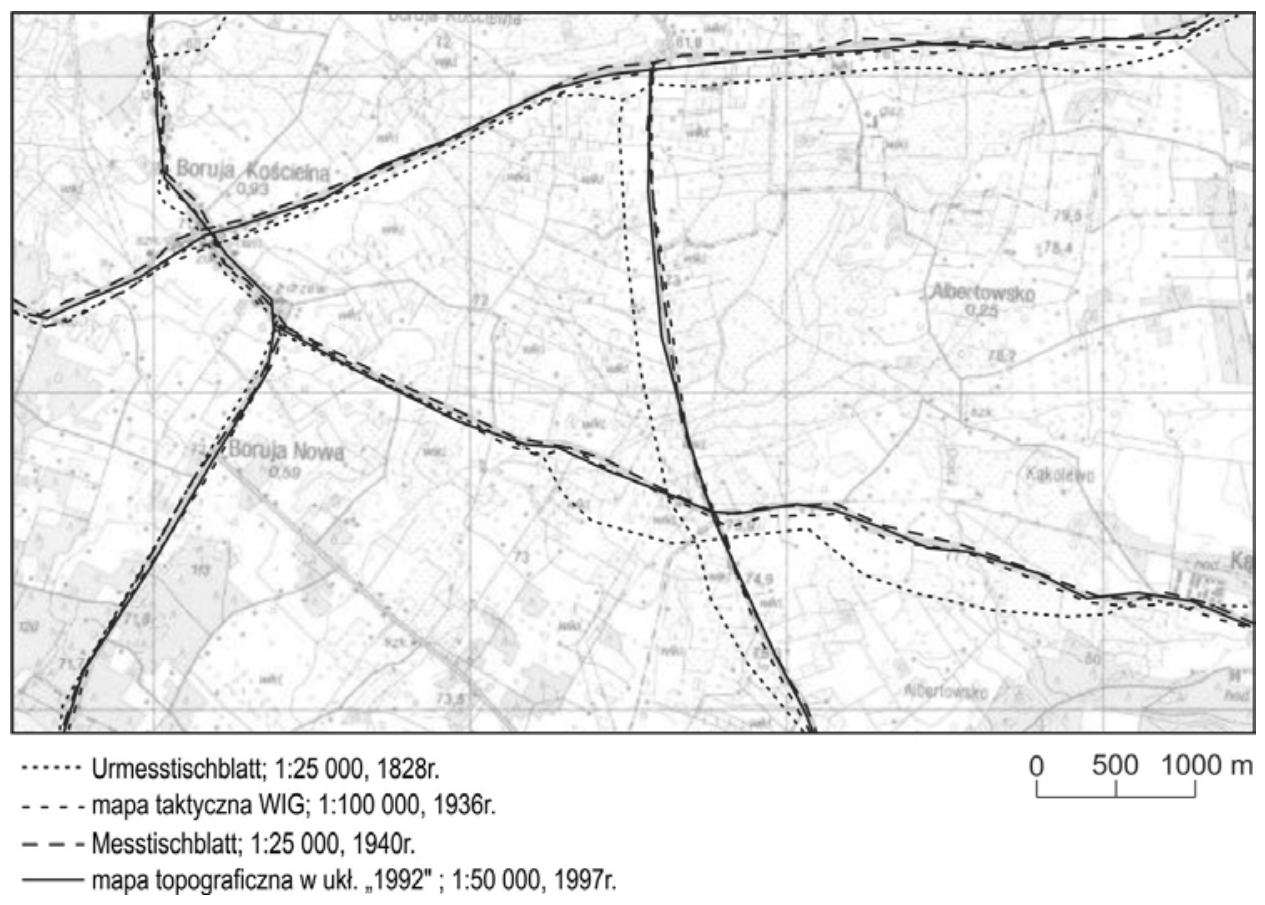

Rys. 2. Niespójność topologiczna po wektoryzacji dróg z czterech map z lat 1828-1997 Źródło: opracowanie własne

Warto dodać, że podobne problemy mogą dotyczyć nie tylko opracowań historycznych, ale także i współczesnych, które również nie są wolne od błędów. Zwrócił na to uwagę J. Wolski (2012) egzemplifikując błędy topologiczne na przykładzie niezgodności cieków z materiałem referencyjnym, co ilustruje rys. 3 . O ile diametralnie różny przebieg rzeki na mapie topograficznej 1:50 000 oznacza zmianę jej przebiegu w rzeczywistości, o tyle różnice między pozostałymi mapami są niewielkie i dość regularne, co sugeruje raczej błędny zapis obiektów do bazy danych niż zmiany przebiegu rzeki. Z kolei M. Goodchild (1993) zdefiniował precyzję danych topograficznych w GIS na ok. 0,5 mm w skali mapy źródłowej, co dla skal 1:25 000, 1:100 000 oraz 1:300 000 wynosi odpowiednio ok. 12,5 m, 50 m i 150 m. Jeśli taka precyzja jest do zaakceptowania dla map współczesnych, to dla archiwalnych, na których błędy położenia obiektów mogą być wielokrotnie wyższe, należy podejść do pojęcia dokładności mapy z większą tolerancją uwzględniającą czas jej opracowania i precyzję ówczesnych narzędzi i metod pomiaru. Dla porównania, według badań A. Koniasa błędy odległości na niemieckiej mapie Urmesstischblatt z lat 30. XIX wieku sięgają ok. $56 \mathrm{~m}$, a na tej z przełomu XIX i XX wieku (Messtischblatt), ok. 44 m, a obie miały opinie bardzo dokładnych i precyzyjnych map jak na czasy, w których zostały opracowane (Konias 2010). 


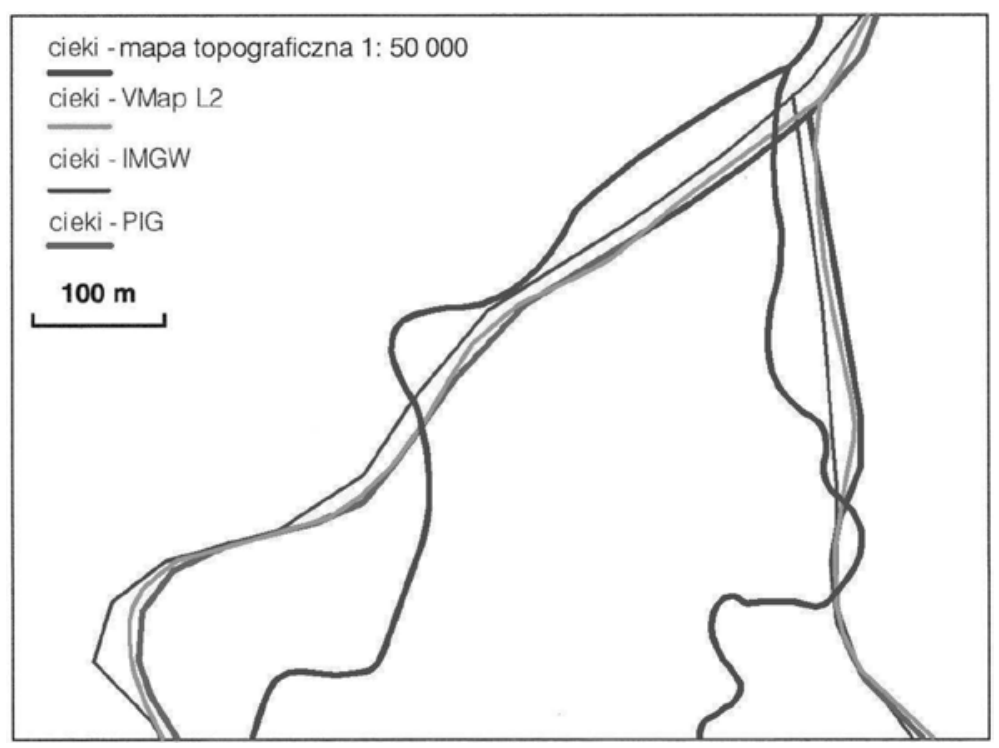

Rys. 3. Przykład braku zgodności cieków z materiałem referencyjnym Źródło: J. Wolski (2012, s. 19)

O ile utrzymywanie w bazie danych zwielokrotnionej geometrii dla obiektu, o którym wiadomo, że nie zmieniał położenia $\mathrm{w}$ ciągu lat jest metodycznie niepoprawne, o tyle znacznie większym problemem jest kwestia ustalenia geometrii dla obiektów, które z pewnością nie są stałymi elementami krajobrazu - rzek, jezior czy lasów. Dochodzimy w tym przypadku do pewnego konfliktu metodycznego. $Z$ jednej strony wektoryzacja treści z niekartometrycznej mapy jest błędna, a z drugiej przyjęcie wspólnego, jednolitego przebiegu dla składowych krajobrazu naturalnego, o których wiemy, że podlegają zmianom również byłoby niepoprawne. Częściowym rozwiązaniem problemu wzajemnej niespójności topologicznej źródeł kartograficznych, względnie ich niewystarczającej kartometryczności może być zastosowanie algorytmów wielomianowych przy kalibracji map rastrowych.

Jednak nawet dla map opartych na precyzyjnych pomiarach terenowych i triangulacji także mogą zdarzyć się drobne przesunięcia obiektów (np. o części milimetra), które jednak spowodują niespójność topologiczną pomiędzy tymi samymi obiektami na różnych mapach (np. między siecią dróg z map WIG i siecią dróg z map niemieckich czy austriackich tego samego okresu). Są to jednak błędy pomijalne, które mieszczą się w precyzji danych zdefiniowanej przez M. Goodchilda (1993), niemniej jednak warto jest mieć świadomość ich istnienia.

Drugim z proponowanych rozwiązań jest wspólna geometria dla danego metaobiektu, na który składają się zidentyfikowane obiekty $\mathrm{z}$ różnych map źródłowych, pomimo różnic w ich położeniu względem siebie. Gdy możliwa jest 
jednoznaczna identyfikacja obiektów z różnych map jako jednego metaobiektu oraz przyjmując, że metaobiekt nie zmienia położenia $\mathrm{w}$ przestrzeni, można ustalić dla metaobiektu wspólną geometrię (tzw. metageometrię). Wspólna geometria jest definiowana jako ta pozyskana z najnowszej analizowanej mapy uznawanej jako najbardziej kartometryczna, na której znajduje się obiekt. Obiekt ten można zidentyfikować z obiektami z map wcześniejszych. W praktyce, jeżeli uznamy kartografię współczesną jako punkt odniesienia, to wszystkie obiekty zidentyfikowane jako te same na wcześniej opracowanych mapach (np. odcinki dróg, zagrody, obiekty terenowe), powinny przyjąć geometrię mapy współczesnej jako najbardziej odpowiadającej rzeczywistemu położeniu. Może się także zdarzyć, że na dawnej mapie znajdzie się obiekt, który zmienił swoje położenie lub przebieg w stosunku do map późniejszych, a jego identyfikacja jest niemożliwa, np. odcinek drogi w przeszłości biegł inaczej niż dziś, a zagrody obecne na mapach w XIX wieku, dziś już nie istnieją. Wówczas informacja geometryczna o takich przypadkach powinna być pozyskana $\mathrm{z}$ najnowszej mapy (względnie najbardziej kartometrycznej), która uwzględnia opisywane obiekty, nawet jeżeli ich zapis obarczony będzie pewnym błędem położenia. Błąd ten można jednak oszacować (np. wykorzystując wskaźnik błędu RMS (Root Mean Square) po kalibracji mapy rastrowej, która była źródłem danych.

Rozwijając metodę Space-Time Composites na dane wektorowe, będzie zatem istniał w bazie danych pewien zestaw metaobiektów (np. odcinków dróg, zagród czy obiektów terenowych). Będzie on stanowił najmniejszą wspólną geometrię (Least Common Geometries; LCG) dla wszystkich obiektów w bazie danych (Langran 1989). Innymi słowy, rolą takich metaobiektów będzie funkcjonowanie jako tzw. instancja globalna dla wszystkich obiektów z map wchodzących w zakres bazy danych. Dla każdego metaobiektu będzie można zdefiniować relację atrybutową między nim a określonym obiektem z mapy źródłowej - tzw. instancji czasowych. Każdy taki metaobiekt zostanie wyposażony $\mathrm{w}$ zestaw informacji, w skład których wejdą: dane o jego położeniu (geometrii), źródle pozyskania (nazwa mapy) oraz unikalny identyfikator. Za jego pomocą możliwe będzie połączenie tabeli zawierającej informacje atrybutowe o obiektach z map źródłowych (np. klasy dróg, nazwy osiedli) z tabelą metaobiektów (relacja wiele do jednego), co ilustruje rys. 4. Unikalny identyfikator metaobiektu („meta_ID”) w tabeli „metaobiekt_geometria” umożliwia zbudowanie relacji z atrybutami obiektu pozyskanymi z różnych map (tabela z danymi atrybutowymi). Źródło atrybutów nie musi być tożsame ze źródłem geometrii, np. w przypadku, gdy mapa jest niekartometryczna i nie można z niej wektoryzować obiektów, ale można pozyskać informacje o nazwie lub kategorii. Takie podejście pozwoli uniknąć redundancji danych geometrycznych, gdyż dla każdego zestawu tożsamych obiektów z dawnych map będzie istniał tylko jeden metaobiekt o zadanym położeniu w przestrzeni. Jego atrybuty będą zmienne $\mathrm{w}$ czasie poprzez definiowanie relacji między nim a danymi z map źródłowych poprzez unikalne identyfikatory. 


\begin{tabular}{|l|l|l|}
\hline \multicolumn{2}{|c|}{ metaobiekt_geometria } \\
\hline meta_ID & geometria & geometria_zrodlo \\
\hline 0001 & $<$ geom $>$ & mapa $\mathrm{X}$ \\
0002 & $<$ geom $>$ & mapa $\mathrm{Y}$ \\
0003 & $<$ geom $>$ & mapa $\mathrm{Z}$ \\
0004 & $<$ geom $>$ & mapa $\mathrm{X}$ \\
0005 & $<$ geom> & mapa X \\
\hline
\end{tabular}

\begin{tabular}{|c|c|c|c|}
\hline \multicolumn{4}{|c|}{ metaobiekt_atrybuty } \\
\hline meta_ID & atrybut_1 & atrybut_2 & atrybuty_zrodlo \\
\hline 0001 & atrybut & atrybut & mapa X \\
\hline 0002 & atrybut & atrybut & mapa X \\
\hline 0003 & atrybut & atrybut & mapa Z \\
\hline 0004 & atrybut & atrybut & mapa Y \\
\hline 0005 & atrybut & atrybut & mapa Y \\
\hline
\end{tabular}

Rys. 4. Propozycja struktury bazy danych Źródło: opracowanie własne

Takie rozwiązanie wydaje się być odpowiednie dla tych elementów krajobrazu, dla których jesteśmy w stanie określić niezmienność obiektu w przestrzeni, a tym samym uznać za ich własność konstytutywną właśnie położenie. Dotyczy to szczególnie składników krajobrazu kulturowego, dla których zmiany przestrzenne są małe (np. poszerzenie drogi, która biegnie tym samym śladem) lub wynikają z przyrostu elementów (np. rozwój miasta czy zwiększanie liczby zagród we wsi). Oczywiście zdarzają się wyjątki, gdzie niemal cały krajobraz kulturowy ulega zniszczeniu lub degradacji (np. Warszawa po drugiej wojnie światowej), ale wówczas geometrię takich obiektów można odtworzyć z najbardziej kartometrycznych map wcześniejszych (np. map WIG) i oznaczyć ten fakt (tj. źródło geometrii) w bazie danych. 
Istotnym problemem, wcześniej już poruszonym, jest sposób zapisu geometrii elementów krajobrazu naturalnego, przede wszystkim rzek i jezior, a także lasów, o których wiadomo, że ich położenie, przebieg lub kształt podlegały zmianom. Meandrującym rzekom czy zmieniającym się pod względem powierzchni lasom nie sposób przypisać informacji o jednolitej geometrii w przestrzenno-czasowej bazie danych. Z drugiej strony, wektoryzacja tych elementów z niekartometrycznych map również nie jest satysfakcjonującym rozstrzygnięciem. Rozwiązaniem tego problemu byłoby pozyskiwanie $\mathrm{z}$ takich źródeł wyłącznie informacji atrybutowej, zaznaczając w odpowiedniej kolumnie bazy danych, że geometria tego obiektu (lasu czy rzeki) jest późniejsza, a jej rekonstrukcja dla okresu wcześniejszego jest niemożliwa ze względu na brak wiarygodnej podstawy źródłowej. W ten sposób, np. z mapy Liesganiga w skali 1:288 000 z 1824 roku, o której wiadomo, że nie była kartometryczna (Faluszczak 2011), pozyskane byłyby jedynie informacje o hydronimach, które odnosiłyby się jednak do późniejszej geometrii rzek, co zaznaczone zostałoby w bazie danych.

Zaproponowana wyżej koncepcja, którą można określić jako „topologię retrogresywną", oparta jest bezpośrednio na metodzie retrogresywnej stosowanej w badaniach historyczno-geograficznych. Ogólne zasady metody retrogresywnej (méthode retrogressive) wprowadzonej do szerszego obiegu przez francuskiego historyka, ojca szkoły Annales, Marca Blocha na początku XX wieku opierają się na założeniu, że na podstawie późniejszych danych można wnioskować o sytuacji wcześniejszej (Leturq 2015). Najczęściej metoda retrogresywna wykorzystywana była do rekonstrukcji krajobrazu naturalnego, np. lasów. Dla serii „Atlasu historycznego Polski. Mapy szczegółowe XVI wieku” założono, że przy braku kartometrycznych źródeł kartograficznych dla epoki wczesnonowożytnej, konieczna będzie rekonstrukcja lasów z map późniejszych, opracowanych na przełomie XVIII i XIX wieku. Uznano przy tym, że o ile nie ma istotnych i wiarygodnych informacji $\mathrm{w}$ źródłach pisanych na temat zmian, o tyle zasięg i kształt lasu z XVI i z przełomu XVIII/XIX wieku był podobny (Słoń 2014).

Praktyczną realizację założeń „topologii retrogresywnej” ilustruje rys. 5. Z kartometrycznego materiału, jaką jest współczesna mapa topograficzna 1:50 000 w układzie „1992”, pozyskane zostały informacje o przebiegu dróg i za pomocą wektoryzacji umieszczone w bazie danych, w tabeli: „metaobiekt_ geometria". Wykorzystując do modelowania metodę LCG, zdigitalizowane drogi zostały podzielone na najmniejsze, jednorodne pod względem atrybutów obiekty (m.in. pogrubiony odcinek). Oprócz zapisu geometrii („,<geom>”) oraz jej źródła („topo50k_1992”) tabela uwzględnia także unikalny identyfikator (,0001”). Do informacji o przebiegu drogi dołączyć można zestaw informacji atrybutowych z innych map, na których ten odcinek także został ujęty (tabela: „metaobiekt_atrybuty”). Relacje między dwoma tabelami są relacjami ,jeden do wielu" $\left(1 \ldots{ }^{*}\right)$, tj. tylko jednemu elementowi z tabeli z geometrią można przyporządkować kilka elementów z tabeli z atrybutami. 


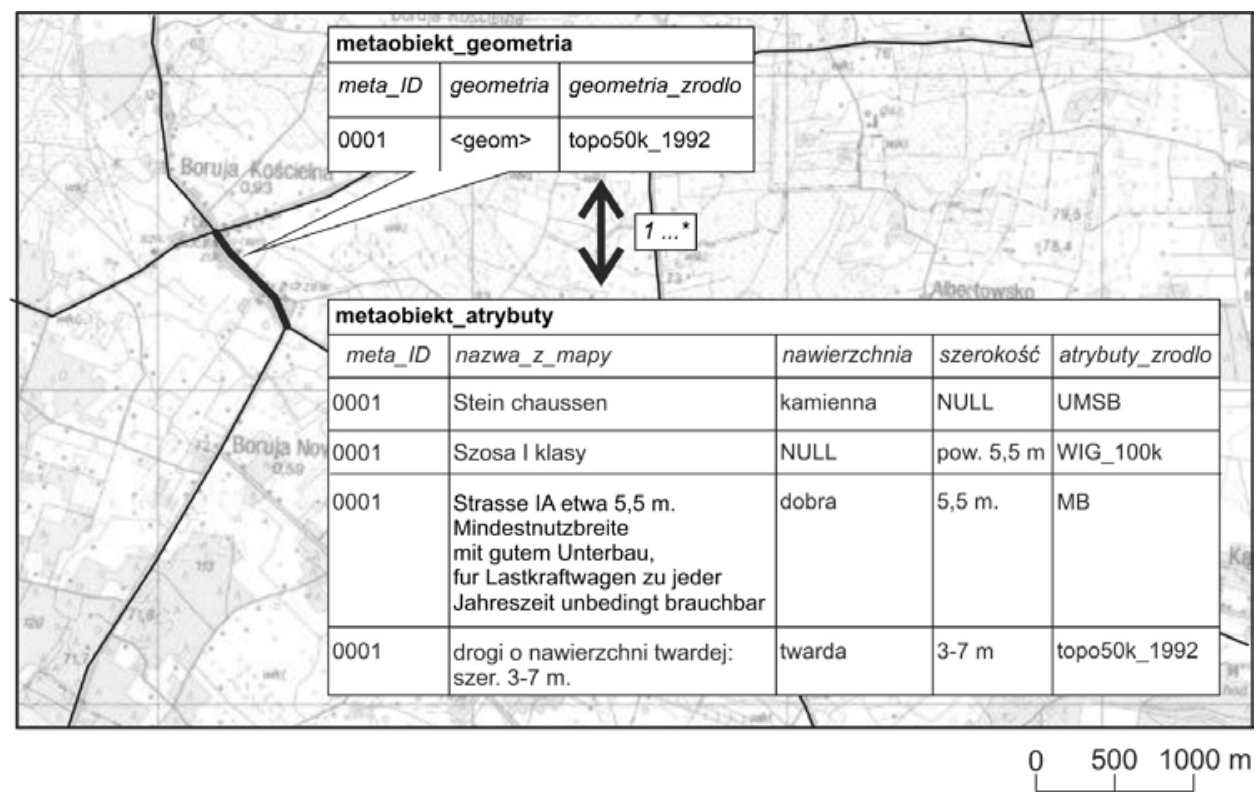

Rys. 5. Przykład relacji pomiędzy metaobiektem a jego atrybutami pozyskanymi z różnych map

Źródło: opracowanie własne

W omawianym przypadku zestaw danych atrybutowych składał się z informacji pozyskanych z czterech map: Urmesstischblatt 1:25 000 (UMSB), Messtischblatt 1:25 000 (MB), mapa taktyczna WIG 1:100 000 (WIG_100k) oraz współczesna mapa topograficzna 1:50 000 (topo50k_1992). Liczba i nazwy kolumn w tabeli dla danych atrybutowych powinny wynikać z charakterystyki danych źródłowych. Zgodnie z założeniami metalegendy (Gołębiowska $\mathrm{i}$ in. 2012; Panecki 2014) konieczna jest kolumna „nazwa_z_mapy”, w której znajduje się opis danej kategorii treści z legendy (w oryginale). Następnie, w przypadku dróg, umieszczono informacje o nawierzchni i szerokości szlaku, które zostały wyekstrahowane $\mathrm{z}$ oryginalnego opisu kategorii. Przyspiesza to wyszukiwanie i indeksowanie informacji z legend, pozwala także analizować zmiany między mapami i je odpowiednio symbolizować itd. Dane do kolumn atrybutowych mogą być także zasilane instrukcjami topograficznymi dla map dawnych. Tak było w przypadku mapy WIG i „Szosy I klasy”, o której wiadomo, że miała powyżej 5,5 m szerokości (Kreutzinger 1928). Jeżeli na danej mapie nie ma informacji o danych atrybutach, pomija się je, wstawiając wartość „NULL”, tj. brak wartości.

Ostatnią kolumną jest ,atrybuty_zrodlo”, która przechowuje informacje o źródle danych atrybutowych $\mathrm{w}$ postaci zdefiniowanego skrótu danej mapy. Celowo nie podaje się informacji o godle, roku wydania arkusza mapy, z których dane zostały pozyskane. Te mogą zostać dołączone na podstawie zapytania 
przestrzennego między tabelami „metaobiekt_geometria” i „metaobiekt_atrybuty" a siatkami skorowidzowymi map, które będą stanowiły integralny komponent bazy danych. Znajdą tam się w miarę dostępności informacje o nazwie i godle arkusza, dacie wydania, dacie aktualności topograficznej czy dacie zdjęcia topograficznego (jako metadane).

\section{Podsumowanie}

Zaproponowana powyżej koncepcja nie rozwiązuje oczywiście wszystkich problemów wynikających z modelowania historycznych danych topograficznych w aspekcie geometrycznym i topologicznym. Ostateczne wnioski będzie można formułować dopiero po szerzej zakrojonych studiach obejmujących swym zasięgiem kartografię ostatniego dwustulecia, a także zróżnicowane pod względem krajobrazu kulturowego i naturalnego obszaru badań. Przyszłe prace z zakresu modelowania historycznych danych topograficznych powinny nie tylko uwzględnić badania o szerokim spektrum przestrzennym i chronologicznym, ale także zostać wzbogacone o refleksję na temat dawnej przestrzeni, jej obrazie w źródłach (zarówno kartograficznych, jak i pisanych), a także możliwości zapisu tych informacji do sformalizowanej struktury bazodanowej. Należy przy tym wskazać potencjalne trudności, jak chociażby kwestie identyfikowania poszczególnych obiektów występujących na różnych mapach (osadnictwa, dróg czy obiektów gospodarczych), zapisywanie obiektów o zmiennej w czasie geometrii, a także tych, co do których niska precyzja źródeł nie pozwala w pełni zrekonstruować ich kształtu, przebiegu czy wielkości.

\section{LITERATURA}

Dukaczewski D., 2005, Elektroniczna mapa animowana Gór Izerskich, „Polski Przegląd Kartograficzny”, 37(1), s. 23-36.

Faluszczak F.P., 2011, Kartografia Galicji Wschodniej w latach 1772-1914, Wydawnictwo Uniwersytetu Rzeszowskiego, Rzeszów.

Głażewski A., 2006, Modele rzeczywistości geograficznej a modele danych przestrzennych, „Polski Przegląd Kartograficzny”, 38(3), s. 217-225.

Gochna M., 2014, Elektroniczna edycja rejestrów poborowych województwa kaliskiego z drugiej połowy XVI wieku, „Studia Geohistorica”, 2, s. 143-150.

Gołębiowska I., Karsznia I., Mikiewicz D., Panecki T., 2012, Towards a historical GIS platform in Poland, [w:] Service-Oriented Mapping 2012, Jobst Media, Wiedeń, s. 417-430.

Goodchild M.F., 1993, Data models and data quality: problems and prospects, [w:] Environmental modeling with GIS, Oxford University Press, Nowy Jork, s. 94-103.

Gregory I.N., 2002, Time-variant GIS databases of changing historical administrative boundaries: a European comparison, „Transactions in GIS”, 6(2), s. 161-178.

Gregory I.N., Healey R.G., 2007, Historical GIS: structuring, mapping and analysing geographies of the past, „Progress in Human Geography”, 31(5), s. 638-653. 
Konias A., 2010, Kartografia topograficzna państwa i zaboru pruskiego od II połowy XVIII wieku do polowy XX wieku, Wydawnictwo Naukowe Akademii Pomorskiej, Stupsk.

Kreutzinger J., 1928, Topografja. Pomiar i zdjęcie kraju, kartografja i wojskowe znaczenie terenu, Wojskowy Instytut Geograficzny, Warszawa.

Langran G., 1989, A review of temporal database research and its use in GIS applications, „International Journal of Geographical Information Systems”, 3(3), s. 215-232.

Langran G., 1992, Time in Geographic Information Systems, Taylor \& Francis, London.

Leturq S., 2015, De l'usage de la méthode régressive en Histoire médiévale, http://www. menestrel.fr/spip.php?rubrique1565 (dostęp: 26.06.2015).

Morillas-Torné M., 2012, Creation of a Geo-Spatial Database to analyse railways in Europe (1830-2010). A Historical GIS approach, „JGIS”, 4(2), s. 176-187.

Nieścioruk K., 2013, Archiwalne materialy kartograficzne źródłem do rekonstrukcji przestrzeni dawnych wsi w strefie zabudowy miejskiej, „Studia Geohistorica”, 1(1), s. 39-47.

Olszewski R., Gotlib D., 2013, Rola bazy danych obiektów topograficznych w tworzeniu infrastruktury informacji przestrzennej w Polsce, Główny Urząd Geodezji i Kartografii, Warszawa.

Panecki T., 2014, Creating a common symbol classification for a new historical geoportal of Poland, „Miscellanea Geographica”, 18(4), s. 34-40.

Reis Ferreira K., Camara G., Vieira Monteiro A.M., 2010, Towards a dynamic geospatial database model, http://mtc-m18.sid.inpe.br/col/sid.inpe.br/mtc-m18/2010/09.20. 14.15/doc/2010_worcap_karineferreira.pdf?languagebutton=pt-BR (dostęp: 26.06. 2015).

Słon M. (red.), 2014, Historical Atlas of Poland in the $2^{\text {nd }}$ half of the $16^{\text {th }}$ century, „Voivodeships of Cracow, Sandomierz, Lublin, Sieradz, Leczyca, Rawa, Plock and Mazovia ; Volume 2, Volume 3, Volume 4”, „Geschichte-Erinnerung-Politik”, 6, we współpracy z Agatą Staszewską i Martha Brozyna, Lang, Peter Frankfurt, Frankfurt am Main.

Szady B., 2010, Granice powiatu tukowskiego w II połowie XVIII wieku - model liniowy i sieciowy, [w:] Narrata de fontibus hausta. Studia nad problematyka kościelna, polityczna $i$ archiwistyczna ofiarowane Janowi Skarbkowi w siedemdziesiata rocznice urodzin, RW KUL, Lublin, s. 831-854.

Szady B., 2013, Czasowo przestrzenne bazy danych jako narzędzie $w$ geografii historycznej, „Acta Universitatis Lodziensis”, Folia Geographica Socio-Oeconomica, 14, s. $17-32$.

Urbański J., 2008, GIS w badaniach przyrodniczych, Uniwersytet Gdański, Gdańsk.

Vrana R., 1990, Historical data as an explicit component of land information systems, [w:] Introductory readings in geographic information systems, Taylor \& Francis, London-New York, s. 286-302.

Wolski J., 2012, Blędy i niepewność w procesie tworzenia map numerycznych, [w:] Źródła kartograficzne w badaniach krajobrazu kulturowego, „Prace Komisji Krajobrazu Kulturowego", Komisja Krajobrazu Kulturowego Polskiego Towarzystwa Geograficznego, 16, Sosnowiec, s. 15-32. 


\title{
MODELLING OF TOPOGRAPHIC OBJECTS IN HISTORICAL DATABASES
}

\begin{abstract}
Large informative potential of archive maps makes them a valuable source of spatial and attribute data for historians, geographers, archaeologists and planners. Since their proper application in GIS (Geographic Information System) often requires a proper database elaboration, there have been proposed several concepts of historical spatial databases. However, they do not include the full range of topographic maps' content, and they were primarily based on secondary data sources (e.g. atlases, dictionaries).

The aim of the paper is to propose the concept of topographic objects' modelling in historical databases which will be based on archived maps in various scales developed over 150 years (eighteenth/nineteenth century - half of the twentieth century). Relating the data with current maps will be available through the connection between planned repository and contemporary spatial databases, e.g. Polish national Database of Topographic Objects (BDOT). In the project materials including Poland in modern borders will be analysed.

Due to the variety of source materials, the main objective of text is to present the initial concept of historical topographic objects' database structure on the example of the integration of topographic data geometry. The problem of how geometry should be stored for each features acquired from the map should be solved. Firstly, each of them can have a separate entry position (Time-slice snapshots) in the database. Secondly, socalled "metaobject" grid with fixed geometry, but variable attributes can be used (Space-time composite).

Since archive maps are characterized by a largely low mathematical precision, therefore its content vectorization without considering the topological relationships between features seems to be incorrect. Maps' elements belonging to the cultural landscape (e.g. settlements, communication network) should rather be stored with fixed geometry and variable attributes. In the contrast, the natural landscape (e.g. hydrography, afforestation), due to the different and difficult to capture changes especially on inaccurate maps (e.g. course of the river) should be stored with individual geometry for each feature depicted on each map.
\end{abstract}

Key words: historical geography, GIS, databases, archival maps, cartographic data modeling.

Mgr Tomasz Panecki Zakład Geoinformatyki, Kartografii i Teledetekcji Wydział Geografii i Studiów Regionalnych Uniwersytet Warszawski 